\title{
PRE-SERVICE ENGLISH TEACHERS' PERCEPTIONS OF PRONUNCIATION
}

\author{
Aina Khoirida \\ Universitas Sebelas Maret, Surakarta, Indonesia \\ E-mail: aina.khoirida@gmail.com
}

Received: 09 January 2020

Accepted: 09 April 2020

\begin{abstract}
The studies that look at pre-service teachers' perceptions of the teaching of pronunciation which is still relatively under-researched in the literature. Previous research on pronunciation commonly gave more attention to the designs to conduct the teaching pronunciation in the classroom, like the methods and the materials. In connection to that, this meant it is leading to what should be taught and how in pronunciation L2 class. This study aimed to look at the pre-service English teachers' perceptions and understanding they are covered about concerning pronunciation teaching. The data for this study was collected through questionnaires with 18 pre-service English teachers from the English Education Department in a public university in Surakarta and interviews with three of them. The findings bring about questions for practice, teachers training, and professional improvement of the participants. The results add to the discussion about the background of the teachers' knowledge related to pronunciation teaching. The issues raised also underline the need for more research in several areas, especially attitude toward pronunciation.
\end{abstract}

Keywords: pronunciation teaching, perception, pre-service English teacher,

\section{Introduction}

In the past two decades, numerous studies have been evidenced by the researchers, that grammar and vocabulary materials received more attention in second language teaching process. Pronunciation has received an 'often neglected' label as well as research, in both theoretical and pedagogical approaches. In the implementation field, research done by Foote (2016), showed that pronunciation teaching is only taught in less than $8 \%$ time total in English teaching duration. However, students of English as a second language need to be able to pronounce English words correctly. Pronunciation is a key component in English language communication. Being able to articulate the right sound is crucial because good pronunciation can deliver the message in communication.

It can be seen, from the teachers' perspective in terms of English teaching, they were not aware whether the learners pronounce the English words correctly or not. As Couper (2017), it was found that the participants in his research, they were unsure of how they should prioritize pronunciation and even how often they should teach pronunciation. It is related and similar to research done by Derwing \& Munro (2015) showed that until 10 years ago, there had been very little research upon which to base any advice on pronunciation teaching. However, there are still few studies done by researchers about pre-service English teachers' perceptions of teaching pronunciation. 
The purposes of this study were to fill the gap by conducting a study, questionnaires and interviews, of actual pre-service English teachers understanding collective and experience gained across a broad range of teaching contexts. The focus is not on any particular group of teachers but rather on pre-service teachers' views, which have been prepared by the university to be ready to teach in the real classrooms. Related to this, the research question asked is: What are pre-service English teachers' perceptions of the teaching of pronunciation?

\section{Literature Review}

The research which has been conducted by Porter (1999), showed that pronunciation has not been the subject of much attention from second language teaching (L2). This viewpoint is supported by Derwing and Munro (2005) who found that the amount of proof about the effectiveness of approaches, methods, and techniques of teaching pronunciation is still very small. However, as with other fields of language elements, especially grammar, the factors in teaching have not been applied correctly (Ellis, 2008). In connection with that, the amount of research on prospective teachers' perceptions about pronunciation is also limited, most research about pronunciation is about the need for better training and professional development (Burns, 2006).

During the 1990s and the early 2000s, intelligibility, suprasegmentals and lingua franca core were the major topics of interest in $\mathrm{L} 2$ pronunciation teaching. In the nativeness principle, the aim of most L2 pronunciation teaching programs until the 1960s was to achieve a nativelike mastery of the target sound system. However, in the intelligibility principle, the aim of most L2 pronunciation teaching programs during the 1990s and the early years of 2000s was to reach a comprehensible speech because having a native-like pronunciation was not possible for all English as Foreign Language (EFL) learners.

Foote (2016) in his research stated that most pronunciation teachings used recast as a response to an error which is often not realized by students as corrective feedback. Foote also stated based on the observation activities reported in the study, there was a tendency to listen-and-repeat as responses to error, although Baker (2014) found teachers who were experienced in his studies wide range activities.

A research study by Couper (2016) informed that teachers of English as Foreign Language (EFL) in Uruguay express the concerns and problems faced by teachers. Also, they stated such as lack of confidence and training in how to teach pronunciation. There was anxiety when using the pronunciation of their non-native English accent as a model. Participants also showed awareness about the importance of pronunciation perceptions and had different views on teaching sound-spelling, used listen-and-repeat activities, and phoneme symbols to teach pronunciation.

As for the place of pronunciation teaching, it can be stated that L2 pronunciation is still neglected in classroom implementation. Few pieces of research have been conducted in this field, but still in little amount number. This research aims to fill the gaps that there is still no research about prospective teachers' perspectives in teaching pronunciation in Surakarta, Indonesia.

\section{Research Method}

The mixed-method research design used to measure participants' perceptions of the pronunciation. It includes both quantitative and qualitative data collection and analysis. The mixing of the method would provide beneficial, complementary, and deeper pieces of information (Johnson \& Crhistensen, 2012). 
This study was conducted at a state university in Surakarta, Indonesia, with pre-service English language teachers as the participants. The target population for this study is a department, the English Education Department, at Sebelas Maret University. From four batches, the batch which was chosen is the seventh semester with a reason that they are still conducting in the third internship, the batch which has the biggest chance or the closest to real teaching in the classroom and applies the pronunciation teaching in their class.

The goal is to verify the readiness and knowledge of prospective English teachers about teaching pronunciation. The purpose also to see how ready they were to teach pronunciation skills after they graduate from university and be teachers in the school. Of the 25 participants of this study, 12 participants were excluded because they did not complete the answers in online-questionnaire. The participants' mean age was 21 (SD=3 years, range $=20-22$ ) with 4 males and 14 females.

The data for this study was accumulated through online-questionnaire and interview. These two methods are chosen to get better understand the perceptions of pre-service English teachers, such as their feelings and their motivations (Fishman et al. 1977). The online questionnaire used because it is very valuable tools for large data collection studies in a short time to meet generalizability in results (King, Lai, \& May, 2017). This questionnaire for the research consisted of three sections; participants' training on pronunciation, participants' knowledge and competence about pronunciation, and participants' perception about the teaching of pronunciation. After the data from the questionnaire were collected, 3 of the participants were chosen randomly to be interviewed to get deeper information. Also, interviewing allows intimacy to grow between the researcher and the participants and therefore deeper sources of data can be obtained (King, Lai, \& May, 2017). The data were collected by methods which already mentioned before, the interview was done by the researcher face-to-face with the participants one by one with each interview took 20-25 minutes. Because of all of the participants were in the last year of college and doing an internship, as well as three interview participants, it was found difficulty in determining the available times with the participants.

\section{Results and Discussion}

Previous studies have shown that several English teachers are still lacking in pronunciation training which they should get in university or teacher training school. According to Couper (2016), the participants in the research explained that they have not been taught insufficient aspects of pronunciation. Some of them only received phonetics and phonology, while the rest only received the articulation of individual sounds or word stress. From that data also can be seen the participants' readiness and confidence in real teachinglearning classrooms after they graduate from the university.

\subsection{Students' training in pronunciation aspects}

According to the findings (Figure 1) which shows students' perceptions about their training on pronunciation, shows that the majority of the participants, 33,3\% of them opine they already got enough training on English pronunciation and $11,1 \%$ of the students strongly agree. While $16,7 \%$ of them are strongly disagreeing and the other $16,7 \%$ disagree. The rest, $22,2 \%$ of the participants are neutral about the number of pronunciation training adequacy. This result indicated that each student has a different 'adequacy' category. Some students thought that the number of training they have got is enough to be their knowledge when they become teachers in the future, but the rest are not thought the same, even they got the same 
time trainings and materials in lecture. In other questions in the online-questionnaire, also shown that they have a different perspective on English phonetics training. Their answers spread evenly from strongly disagree to strongly agree related to this question. While in another question about their training in the varieties in English accents, 38,9\% of students opined agree and the majority, $44,4 \%$ of them opined neutral. These answers related to the introduction of native English accents and some English as a Lingua Franca (ELF).

\section{I have got enough training on English pronunciation before this on campus}

18 responses

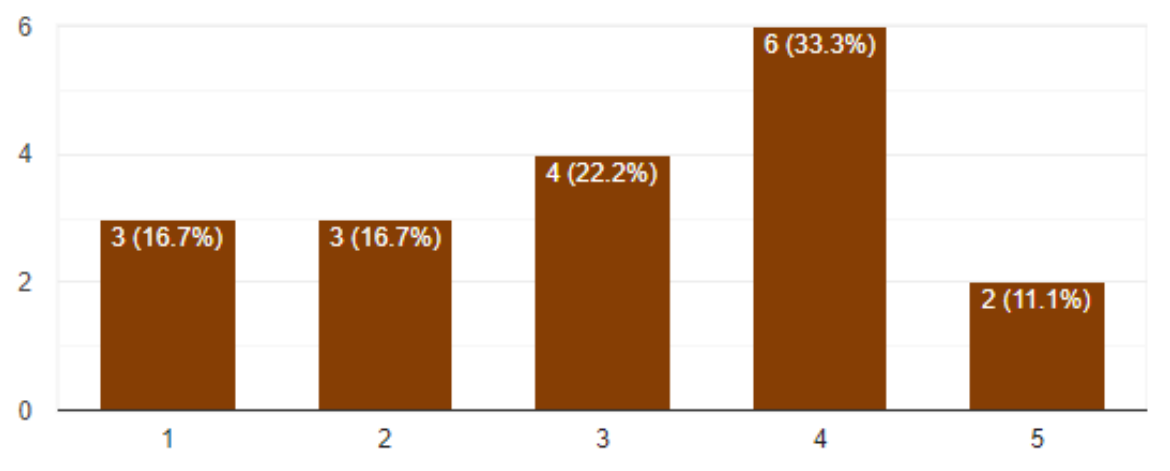

Figure 1. Students' perceptions of their pronunciation training.

Thus, the data is in line with research conducted by Couper (2016) which said that even though they have received the same training in pronunciation, it is normal if they have different perceptions. In that research conducted by Couper, participants showed different readiness. From the three students I have interviewed, two of them said that pronunciation training they have got is enough. They said that they got the basics and concepts of pronunciation, and other lessons like in the listening class to distinguish sounds or pronunciation by the speakers, phonetics, and phonology, etc. They also said that it is 'enough' if it talked about the base and the concept of pronunciation. While the other one said it is still not enough because pronunciation is the main point in English, especially in speaking. She also added that it should be more training not only in the first or second semester. Furthermore, they need more opportunities to practice in the classroom so they not only know the concept but also the skills.

These findings indicated that the amount or the effectiveness of training will have an impact on the implication of pronunciation teaching in the classrooms by preservice English teachers. Therefore, the main reason for instructors or teachers confronting difficulties with pronunciation instruction seems to be the lack of sufficient training in pronunciation pedagogy included in L2 teacher preparation programs (Burgess \& Spencer, 2000; Burns 2006; Foote et al., 2011; Henderson et al., 2012; J. Murphy, 1997; Sicola \& Darcy, 2015). Also, to the lack of opportunities for $\mathrm{L} 2$ teachers to learn how to teach pronunciation, little is known about how they are prepared to teach pronunciation in their future classrooms, as few studies have been conducted in this context. 


\subsection{Students' knowledge and competence in pronunciation}

Figure 2. shows the knowledge and competence of the students in pronunciation. In general, the majority of them, $50 \%$ chose neutral for the question of whether or not they have good or correct English pronunciation. 38.9\% of them agree while the remaining $11.1 \%$ disagree. This result means that many of the participants think they have or can pronounce correctly but on a normal or standard range, not bad or very good. This distribution of answers also occurs in the other questions. From phonetic mastery and understanding questions, most of them, $44.4 \%$, also chose neutral. $38.9 \%$ of them chose to agree and the rest chose to disagree. While in the English word stress question, $66,7 \%$ of students chose neutral. $27,8 \%$ chose to agree and the rest chose to disagree. So, the figure shows almost the same proportions, the majority of their answers only spread in neutral and agree on the scale. If this condition was connected to their readiness to teach their students in the future, it can be concluded that they still lack and need more training to be a better one.

\section{I have good/correct English pronunciation}

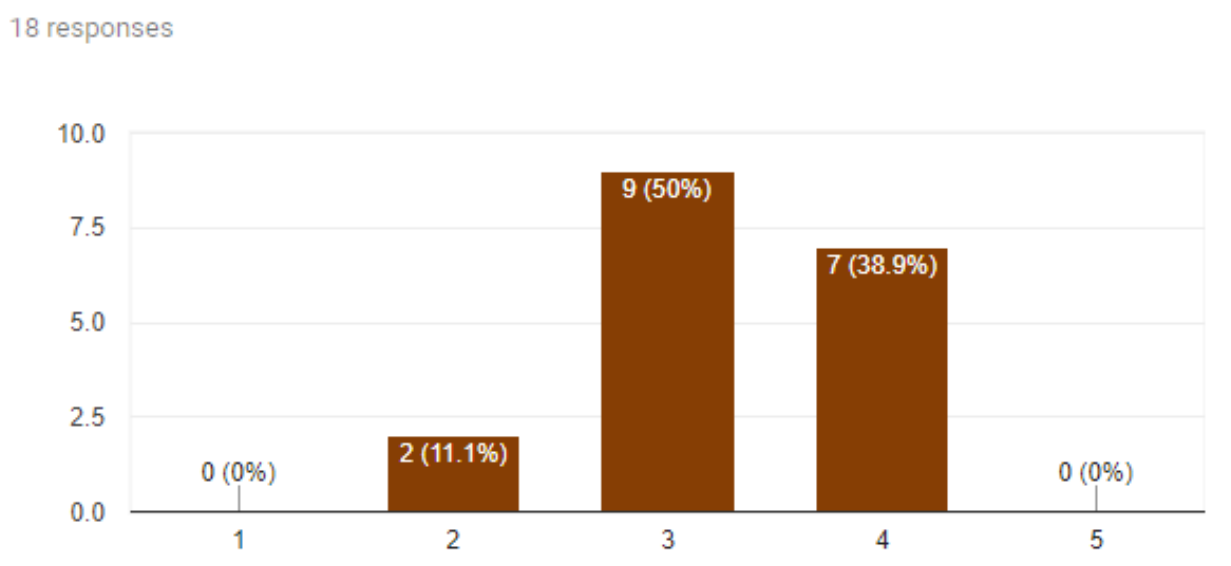

Figure 2. Students' knowledge and competence in pronunciation

The research conducted by Gürsoy \& Hüseyinoğlu (2017) also showed the same result. The teachers-in-training were not sure whether their pronunciation of English is good, nor were they content with their pronunciation. From the three students whom I interviewed, related to their competence in pronunciation, I asked them about how they will teach their students with this condition. Their answers were various. One of them said, "When I will be a teacher, first, I should give them the best models of correct pronunciation in everyday classes so that they will get used to hearing the correct one. Second, provides them with learning sources such as authentic video/audio, but still, need to select the appropriate one for their level. Third, pronunciation drilling for the word. Give corrective feedback of mispronouncing words by students. Fourth, give them a project-based task like producing a video (adjusted with the topic being learned)". While the remaining two said, they will use drilling as a method as the lecturers taught them in university.

This result proved once again fact in the field that has been found by previous researchers. The reasons linked with why pronunciation teaching is challenging embrace a variety of factors, including teachers' lack of confidence, inability to lecture pronunciation 
systematically, and uncertainty about what aspects of pronunciation to teach and how to use textbooks and materials in their classrooms effectively (Baker, 2011a). Further adding to the complexity of teaching pronunciation is that there is no agreed-upon system of deciding what to teach, and when and how to do it (Darcy, Ewert, \& Lidster, 2012). One of the reasons for this unsystematic approach is that pronunciation teaching, to a large extent, depends on instructors or teachers' institutions and pedagogical beliefs (Hismanoglu \& Hismanoglu, 2010; Levis, 2005). Carrying on one's own L2 language learning experience often results in traditional techniques, such as drills and repetition, being predominantly used in the classroom (Baker, 2014; D. Murphy, 2011) due to the inclination of instructors to fall back onto techniques they experienced themselves as L2 learners.

\subsection{Students' perceptions about the teaching of pronunciation}

Figure 3. Presents the result of students' perceptions of pronunciation teaching. The majority of the students, $55,6 \%$ strongly agree with the pronunciation teaching to their students. $38,9 \%$ of them agree and only one student or $5,6 \%$ said neutrally. It indicated that they thought pronunciation is an important material to be taught to the students. Just like in another question, about pronunciation mastery must be mastered by everyone or students, half of them or $50 \%$ said to agree. Strongly disagree was chosen by $38.9 \%$ of the students, while the rest or $5,6 \%$ of them chose neutral and the other $5,6 \%$ chose to disagree. Then, the last question was about students' confidence to teach pronunciation, the majority of the student or $55,6 \%$ said that agree that they are confident and ready enough and $5,6 \%$ or one of them said strongly disagree. Six of them or $33,3 \%$ said neutrally. While the other $5,6 \%$ said disagree.

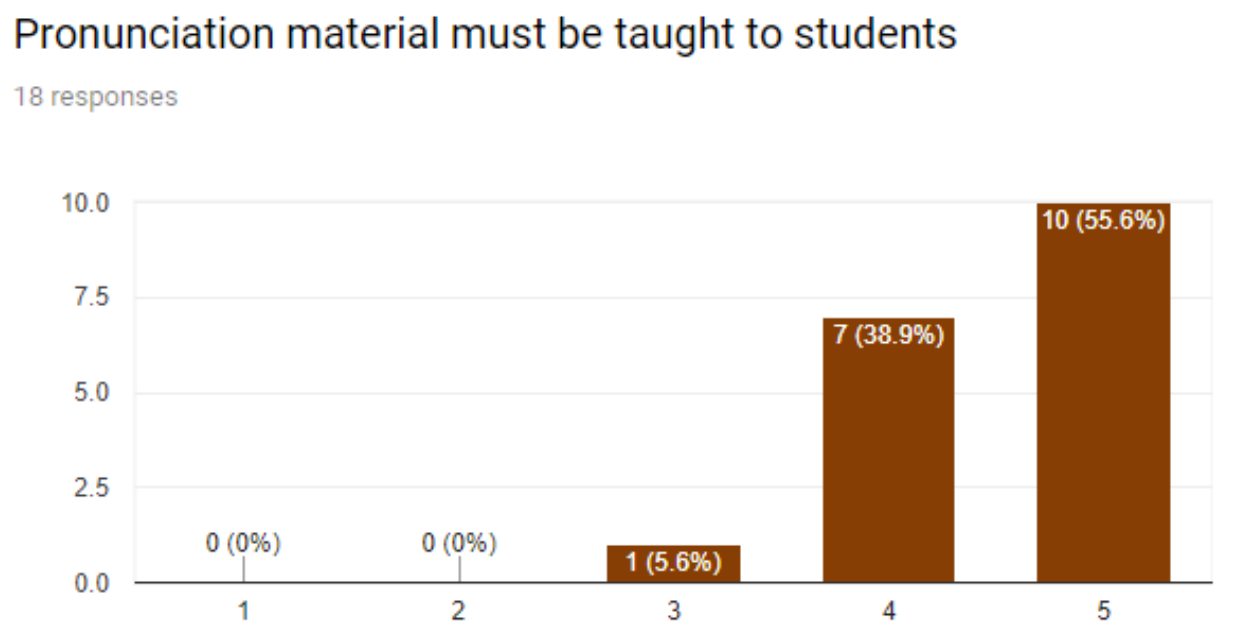

Figure 3. Students' perceptions about the teaching of pronunciation

This result is in line with research which was conducted by Gürsoy \& Hüseyinoğlu (2017). From three students whom I interviewed, three of them answered because pronunciation is an important skill in English, especially in speaking. One of them said, "Everyone will say that you have a good language skill, relatively, based on how good is your pronunciation not from another aspect. And the other reason is when you want to try to speak with foreigners, in this case, English speakers the only way they can understand what you are saying and what are your intentions are if you can deliver them in a pronunciation that can be 
understood by them, which is a good one." While the other said, "pronunciation is one of the important aspects when learning English because when someone can pronounce words correctly, the means of communication will be conveyed well."

From these findings, it can be concluded that not all teachers are aware of the importance of pronunciation. The majority of teachers think that pronunciation study is too difficult and monotonous for learners (Harmer, 2001). Kenworthy (1987) said that there are just some students who know the value of good pronunciation. This is the responsibility of teachers to persuade their learners to study pronunciation severely and help them learn to pronounce English sounds correct. Teachers should tell their students if students do not practise good pronunciation at the beginning of their learning process, they may learn wrongly. Therefore, words should be learnt regarding their pronunciation. Otherwise, this may damage learners' overall success. Accordingly, Field (2005) and Hahn (2004) in their research, support the claim that pronunciation-related issues affect how interlocutors understand one's message.

\section{Conclusion}

The current research has answered the research question that is pre-service English language teachers' perceptions related to pronunciation teaching. While from the previous studies, this topic is still under-researched. Most of them were talking about the methods and how to teach pronunciation, not about teachers or pre-service teachers' perceptions. The perceptions in this study focused on 1) training on pronunciation, 2) competence and knowledge, and 3) perception about pronunciation teaching. It is not only restricted to those three aspects, but also the method and ideal practice of pronunciation. This research also tried to know their planning and view related to this topic, when they become teachers in the future.

The results have shown how enthusiast the participants are to teach pronunciation in their classrooms. It is also shown that they have sufficient planning in methods or ways to approach to give a good understanding to their students. The importance of teaching pronunciation has been realized by the students and they wanted to implement or teach their students about it. However, the university was not giving them sufficient preparation, either in materials or how to teach that. So, they hoped the university will fix it and give good preparation for their future teachers. Because English teachers should master well as one of these language elements. Additionally, the results also showed that the majority of the participants did not feel confident enough about their competence in pronunciation, either the word stress or how to pronounce words.

Thus, this result suggests the need for better preparation and curriculum in university that is increasing the opportunity for the students to have good pronunciation. Based on the result, the students showed that the amount of they could practice their pronunciation was low. They received 'enough' number of materials but still lacked in practice, so that was the reason the students still not confident with their pronunciation skills. Therefore, more research is needed to reiterate these results and topic in different contexts and aspects of teaching pronunciation. Lastly, it also suggests the next researches on other variables, such as the in-service teacher perceptions, to validate and see the differences with the finding of this research. 


\section{References}

Baker, A. A. (2011). Discourse prosody and teachers' stated beliefs and practices. TESOL Journal, 2(3), 263-292. DOI: 10.5054/tj.2011.259955

Baker, A. (2014). Exploring teachers' knowledge of second language pronunciation techniques: Teacher cognitions, observed classroom practices, and student perceptions. TESOL Quarterly, 48, 136-163. DOI:10.1002/tesq.99.

Burgess, J., \& Spencer, S. (2000). Phonology and pronunciation in integrated language teaching and teacher education. System, 28(2), 191-214. Doi: 10.1016/S0346$251 \times(00) 00007-5$

Burns, A. (2006). Integrating research and professional development on pronunciation teaching in a national adult ESL program. TESL Reporter, 39,34-41.

Couper, G. (2016). Teacher cognition of pronunciation teaching amongst English language teachers in Uruguay. Journal of Second Language Pronunciation, 2(1), 29-55. DOI:10.1075/jslp.2.1.02cou.

Couper, G. (2017). Teacher Cognition of Pronunciation Teaching: Teachers' Concerns and Issues. TESOL Quarterly, 51(4), 820-843. https://doi.org/10.1002/tesq.354.

Darcy, I., Ewert, D., \& Lidster, R. (2012). Bringing pronunciation instruction back into the classroom: An ESL teachers' pronunciation "toolbox". In J. Levis \& K. Lavelle (Eds.), Proceedings of the 3rd Pronunciation in Second Language Learning and Teaching Conference (pp. 93-108). Ames, IA: Iowa State University.

Derwing, T., \& Munro, M. (2005). Second language accent and pronunciation teaching: A research-based approach. TESOL Quarterly, 39, 379-397. DOI:10.2307/3588486.

Derwing, T., Munro, M., (2015) Pronunciation fundamentals: Evidence-based perspectives for L2 teaching and research. Amsterdam, the Netherlands: John Benjamins.

Dornyei, Z. (2011). Research methods in applied linguistics: Quantitative, Qualitative and mixed methodologies. Oxford: Oxford University Press.

Ellis, R. (2008). The study of second language acquisition (2nd ed.). Oxford: Oxford University Press.

Field, J. (2005). Intelligibility and the listener: The role of lexical stress. TESOL Quarterly, 39(3), 399-423.

Fishman, J. A., Cooper, R. L., \& Conrad, A. W. (Eds.). (1977). The spread of English: The sociology of English as an additional language. Rowley: Newbury House.

Foote, J. A., Holbty, A. K., \& Derwing, T. M. (2011). Survey of the teaching pronunciation in adult ESL programs in Canada, 2010. TESL Canada Journal, 29 (1), 1-22. Doi: 10.18806/tesl.v29il.1086

Foote, J. A., Trofimovich, P., Collins, L., \& Soler Urzua, F. (2016). Pronunciation teaching practices in communicative second language classes. Language Learning Journal, 44, 181-196. DOI:10.1080/09571736.2013.784345.

Gürsoy, E., \& Hüseyinoglu, M. (2017). ELT Teacher Trainees' Self-Perceptions and Awareness of the Pronunciation Skill, and Their Attitudes towards Its Instruction. Novitas-ROYAL (Research on Youth and Language), 11(2), 169-183.

Hahn, L. (2004). Primary stress and intelligibility: Reseach to motivate the teaching of suprasegmentals. TESOL Quarterly 38(2), 201-223.

Harmer, J. (2001). The Practice of English Language Teaching. London: Longman.

Henderson, A., Frost, D., Tergujeff, E., Kautzsch, A., Murphy, D., Kirkova-Naskova, A., . . . Curnick, L. (2012). The English pronunciation teaching in Europe survey: Selected results. Research in Language, 10(1), 5-27. DOI: 10.2478/v10015-011-0047-4 
Hismanoglu, M., \& Hismanoglu, S. (2010). Language teachers' preferences and pronunciation teaching techniques: Traditional or modern? Procedia: Social and Behavioural Sciences, 2(2), 983-989. DOI: 10.1016/j.sbspro.2010.03.138

Johnson, B. and Christensen, L. (2012). Educational research: Quantitative, qualitative and mixed approaches (4th ed.). Thousand Oaks, US: Sage publications.

Kenworthy, J. (1987). Teaching English Pronunciation. Longan, Harlow.

King, K. A., Lai, Y.-J., \& May, S. (2017). Research methods in language and education (3rd ed.). Cham: Springer. DOI: 10.1007/978-3-319-02249-9

Levis, J. (2005). Changing contexts and shifting paradigms in pronunciation teaching. TESOL Quarterly, 39(3), 369-377. DOI: 10.2307/3588485

Maxwell, J. A. (2013). Qualitative research design: an interactive approach (Vol. 41). Thousand Oaks, CA: SAGE Publications.

Murphy, D. (2011). An investigation of English pronunciation teaching in Ireland. English Today, 27(4), 10-18. DOI: 10.1017/S0266078411000484

Murphy, J. (1997). Phonology courses offered by MATESOL programs in the U.S. TESOL Quarterly, 31(4), 741-764. DOI: 10.2307/3587758

Porter, D. (1999). Pronunciation. Concise encyclopedia of educational linguistics. 647-652. Oxford, MS: Pergamon Elsevier.

Sicola, L., \& Darcy, I. (2015). Integrating pronunciation into the language classroom. In M. Reed \& J. Levis (Eds.), The handbook of English pronunciation (pp. 471- 487). Malden, MA: Wiley Blackwell. 